\title{
LIGHTNING PROTECTION SYSTEMS IN STABLES
}

\author{
Francesco Santoro ${ }^{1}$, Artur Przywara ${ }^{2}$, Pawel Sobczak ${ }^{2}$, \\ Artur Kraszkiewicz ${ }^{2}$, Alexandros Sotirios Anifantis ${ }^{1}$ \\ ${ }^{1}$ University of Bari Aldo Moro, Italy; ${ }^{2}$ University of Life Sciences in Lublin, Poland \\ francesco.santoro@uniba.it, artur.przywara@up.lublin.pl,pawel.sobczak@up.lublin.pl, \\ artur.kraszkiewicz@up.lublin.pl, alexandrossotirios.anifantis@uniba.it
}

\begin{abstract}
Agricultural activities are more often linked to the use of electrical and electronic devices. The evolution of climate with a continuous increase of thunderstorm phenomena, more and more concentrated and intense, need to raise attention by users about the protection of structures and equipment against overvoltage phenomena of atmospheric origin. The combination of thunderstorm phenomena and the high sensitivity to induced and conducted electromagnetic phenomena of equipment could origin failures that could affect productivity and safety. By a safety point of view, in Italy the law obliges the employers to assess the risk raised by lightning effects in order to ensure that the buildings, systems, structures, equipment are protected in agreement with the national and international technical standards. Considering the agricultural-livestock sector, the new Italian guidelines need that farmers should re-examine structures referring also to the compatibility with animal protection requirements. In the event of a fault, considering the high sensitivity to electrical effects on animal health, it is necessary to limit contact voltages to negligible values, by means of additional equipotential connections among all the masses present in the plant (both strictly useful and not for the main proactive activity). Furthermore, considering the dimension of animals compared to that of humans, particular care has to be taken in limiting the step voltage also connecting the electro-welded nets used to reinforce the concrete floor of animal shelters to ground collector. The main goal of this work is to analyse the technical standard concerning the protection from lightning with particular regard to the agricultural-livestock sector and to study the principal equipment and parts useful to set up an effective lightning protection system for a medium-sized stable.
\end{abstract}

Keywords: lightning protection systems, safety, agricultural-livestock sector.

\section{Introduction}

Italy is yearly hit by about 600000 lightning strokes, which means about 2 strokes per $\mathrm{km}^{2}$ with a distribution that, obviously, depends also on geomorphology [1-11]. Lightning bolts are originated in cumulus clouds, where small crystals of ice and water drops, due to friction and/or nebulization, are electrically charged and give rise to high intensity electric fields that trigger the discharge mechanism [12-24].

As for other possible occupational and safety health concerns in agricultural activities [25-29] lightning can be a huge risk also due to the unawareness of workers, so, in order to have a good protection from dangerous effects of these phenomena a Lighting Protection System (LPS) should be used. It's composed by: an uptake device, a protection equipment against lighting-generated electromagnetic pulse (Lightning Electro Magnetic Pulse-LEMP), a LEMP-generated overvoltage protection device (Sourge Protection Measures-SPM) and a set of other minor and complementary devices to prevent lightning side effects, such as fire, high-tech and structural damages [28; 29].

A lightning stroke can hit on structures (directly or nearby) and on power lines (directly or nearby) [30-33], producing damages to living beings by electrocution, fire, explosions, mechanical damages, electrical and electronic damages due to LEMP induced or conducted by power lines or by the radiates of electro-magnetic field itself [34-37]. Each of the above-mentioned effects can result in damages to humans or even to the loss of human lives, in faults in public services, in cultural heritage damages and last, but not the least, in economic losses.

To prevent a possible damaging effect,the LPS is, so, composed by: [38]:

1. External LPS that has to intercept the lightning by means of a pick-up system and has to conduct the lightning current to the ground using an earth sink;

2. Internal LPS that must prevent dangerous shocks inside the structure. For this aim equipotential connections between metal bodies and/or separation distance among them are needed, as well as the insertion of the Surge Protective Device (SPD) on the power lines. The internal LPS is needed, because when a lightning protection system is picked-up by external LPS, voltages of hundreds of kilovolts affect each part of the whole LPS and, thus, high potential differences arise, due to the impulses resistive and/or inductive coupling mechanism, between the protection 
system, protected structure, objects and sensitive equipment that are more and more used in agricultural sector for production, decision and design [39-57].

It has to be considered, furthermore, that the possible need to design an LPS always starts from the risk of fulmination evaluation [58-61]: if higher than the acceptable one, it should be designed, otherwise the structure is self-protected and it is possible to avoid the LPS design and construction $[59 ; 60]$. In the estimation of the acceptable risk must be considered all the previously reported possible damaging effects: human lives losses, public service faults and cultural heritage losses $[60 ; 61]$.

Regarding the structures used in the agricultural and zootechnical sector, considering the high sensitivity of animals to differential potential, particular care must be taken in lowering touch and step voltages; so, the present work aims to analyse the main topics related to the construction of a LPS for protection of a stable to be built that will host 200 animals and where 10 employees will work. This protective measure is not considered compulsory by lightning protection Italian legislation, but, nevertheless, considering the high economic investment and the presence of workers, with the aim to grant safety, construction of a lightning protection system can be considered highly recommended.

\section{Materials and methods}

The evaluation carried out in this paper relates to a stable that is going to be built within a farm located near Tursi (Matera District, Southern Italy - 40.24739 N 16.44855 E). The stable will have a length, $L=20 \mathrm{~m}$, a width, $W=50 \mathrm{~m}$, a roof height with a minimum of $5 \mathrm{~m}$ and a maximum, $H=7 \mathrm{~m}$. It will host about 200 beef cattle and about 10 workers will work to care and manage the animals. The stable design and construction will give attention in reducing costs, while ensuring both high operational functionality in animal management and high safety and comfort for workers. Different materials and construction techniques will be used with particular care in choosing the ones that best suit the need to reduce possible direct or indirect effects of lightning hitting:

- Reinforced concrete for main structural parts (foundations, floors, pit grating);

- Wood (both laminated and solid) for walls and roof frames;

- Insulated metal roof cover;

- Light and plastered brick for partition walls;

- Tiles for hygienic sensitive floors (milk room and toilettes);

- Galvanized metal for doors and windows.

Based on the results of the presented study, the opportunity to install an LPS has been considered to achieve an additional safeguard for the forthcoming business activity in terms of human, animal, device and structure protection. The LPS will protect the stable from direct lightning and, therefore, from possible fire or from the consequences of the lightning current itself (lightning without ignition) taking care of the following regulations in force:

- General principles on the "lightning protection systems (LPS)" of structures and connected technical installations $[58 ; 59]$;

- Lightning on the ground risk assessment [58; 59];

- Design, installation, verification, and maintenance criteria of the LPS for limitingstructures' material damage and people risks [60];

- SPM design to protect electrical and electronic systems against LEMP [61].

\section{Results and discussion}

The lightning damage risk $\mathrm{R}$ that must be considered as the sum of all the $\mathrm{R}_{\mathrm{x}}$ risks relevant for specific type of possible losses that, in this case, are: 1) loss of human lives; 2) economic losses.

With reference to the latter, as no data were available, for this analysis the representative value of acceptable risk has been considered [59-61].

The $\mathrm{R}$ risk for losses of human lives is given by the following equation:

$$
R=N \cdot P \cdot L,
$$

where $N$-number of lightning strokes per year on the evaluated surface; 


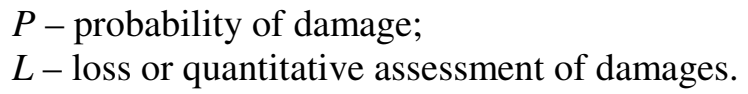

To evaluate the potential risk, it has to be evaluated on statistical basis, the average number of lightning per $\mathrm{km}^{2}$ : the lightning density value on the ground $N_{g}$. This evaluation is made possible by means of the lightning stroke localization networks (LLS) covering the whole Italian territory [38]

$$
N_{g}=2.62 \frac{\text { lightning }}{\mathrm{km}^{2} \cdot \text { year }} .
$$

The right number $\mathrm{N}$ of dangerous events that could really affect the stable must be evaluated relating the lightning density on the ground $N_{g}$ with the collection area equivalent to the stable [58]. It is necessary to evaluate the lightning frequencies that may affect the stable, considering four different parameters: direct lightning stroke on the structure $\left(N_{D}\right)$; lightning stroke that produces magnetic effects $\left(N_{M}\right)$; direct lightning stroke on power lines $\left(N_{L}\right)$; lightning near the power lines $\left(N_{I}\right)$.

Taking care of the stable characteristics (internal flooring, presence of people, layout of the internal installations, etc.), a single homogeneous area has been considered for evaluating, for it: the equivalent direct lightning stroke collection surface $\mathrm{S}_{\mathrm{D}}$; the equivalent indirect lightning stroke collection surface $S_{M}$; the equivalent direct lightning on power lines collection surface $\mathrm{S}_{\mathrm{L}}$ and the equivalent indirect lightning on power lines collection surface $S_{I}$ (Figure 1) [58].
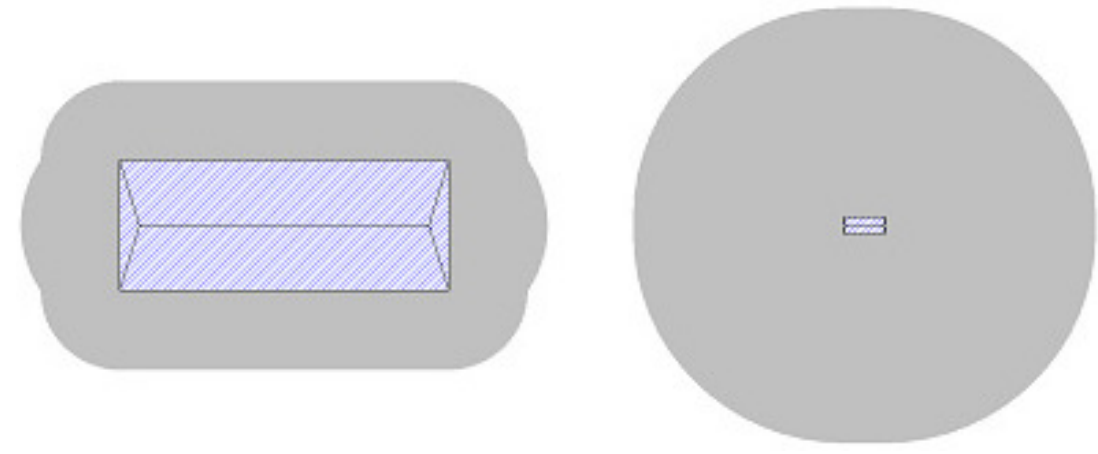

Fig. 1. Collection area for both direct $\left(S_{D} \& S_{L}\right)$ and indirect $\left(S_{M} \& S_{I}\right)$ lightning strokes on structure and on power lines

The following data have been obtained:

$$
\begin{aligned}
& S_{D}=3.22 \cdot 10^{-3} \mathrm{~km}^{2}-S_{M}=4.36 \cdot 10^{-1} \mathrm{~km}^{2} \\
& S_{L}=8.00 \cdot 10^{-3} \mathrm{~km}^{2}-S_{I}=8.00 \cdot 10^{-1} \mathrm{~km}^{2},
\end{aligned}
$$

allowing to evaluate the corresponding numbers of dangerous events due to direct and indirect lightning strokes on the structure $\left(N_{D}, N_{M}\right)$ and for direct and indirect lightning strokes on the power lines $\left(N_{L}, N_{I}\right)$ [59-62]:

$$
\begin{aligned}
& N_{D}=0.016900 \text { year }^{-1}-N_{M}=1.140000 \text { year }^{-1} \\
& N_{L}=0.010480 \text { year }^{-1}-N_{I}=1.048000 \text { year }^{-1} .
\end{aligned}
$$

Finally, assessing to be $1 \%$ probability of damage to living beings $\left(P_{A}\right)$, to the structure $\left(P_{B}\right)$, to the installations $\left(P_{C}\right)$ and of failure of the installations $\left(P_{M}\right)$,it was possible to evaluate that the risk deriving from fulmination for the considered structure $R$ that is, in this case, lower than the acceptable risk $R_{T}$ allows to consider the structure itself as self-protected and permitting to not install alightning protection system:

$$
R=3.38 \cdot 10^{-6}<R_{T}=1.00 \cdot 10^{-5}
$$

As an additional caution to reduce step and contact voltage is, nevertheless advisable, adding an electro-welded steel net in the concrete base, to provide equipotential connections among all metal bodies (also concrete reinforcement ones) with an efficient ground sink made of a bare copper rope buried along the entire external perimeter of the stable and 4 linear sinks placed at the vertices of the structure at a depth not less than 6 meters. 


\section{Conclusions}

Modern agriculture widely uses computer and electrical systems to increase profitability with the aim to optimize and automate the most time-consuming processes. In agricultural in general and in livestock plants in particular, lightning can have particularly serious consequences for the structures also in consideration of their geographical location, their construction technique or their use. Remembering that nowadays frequent agricultural buildings are equipped with robotic milking systems and considering that, often, all the equipment needs to achieve such task controlled through data lines and that they can be controlled from remote locations, it appears clear why it is recommended to install protective measures against both lightning and overvoltages. Even, if what has been considered in this study is a quite small stable, the methodology used could be considered to be a possible approach that, taking into account the technical standard, which defines the technical and design procedures in the field of protection from lightning with reference to the agricultural-livestock sector, could be used in the design of a medium and large-sized stable, in which, for sure, the risks are more relevant. The presented study has to be considered as an innovative approach in stable design, which, in the absence of regulatory obligations, allows to evaluate the opportunity to install an LPS to achieve an additional safeguard for the forthcoming business activity in terms of human, animal, device and structure protection.

\section{References}

[1] Mona T., Horváth À., Ács F. A thunderstorm cell-lightning activity analysis: The new concept of air mass catchment. Atmos. Res., vol. 169, 2016, pp. 340-344.

[2] Betz H.D., Schmidt K., Laroche P., Blanchet P., Oettinger W.P., Defer E., Dziewit Z., Konarski J. LINET an international lightning detection network in Eu. Atmos. Res., vol. 91(2-4), 2009, pp. 564-573.

[3] Carey L.D., Buffalo K.M. Environmental control of cloud-to-ground lightning polarity in severe storms. Mon. Weather Rev., vol. 135, 2007, pp. 1327-1353.

[4] Dixon M., Wiener G. TITAN: Thunderstorm Identification, Tracking, Analysis, and Nowcastinga radar-based methodology. J. Atmos. Ocean. Technol., vol. 10, 1993, pp. 785-797.

[5] Feudale L., Manzato A. Cloud-to-ground lightning distribution and its relationship with orography and anthropogenic emissions in the Po Valley. J. Appl. Met. Climatol., vol. 53(12), 2014, pp. 2651-2670.

[6] Gatlin P.N., Goodman S.J. A total lightning trending algorithm to identify severe thunderstorms. J. Atmos. Ocean. Technol., vol. 27 (1), 2010, pp. 3-22.

[7] Gatlin P.N., Goodman S.J. A total lightning trending algorithm to identify severe thunderstorms. J. Atmos. Ocean. Technol., vol. 27 (1), 2010, pp. 3-22.

[8] Qie X., Liu D., Sun Z. Recent advances in research of lightning meteorology. J. Meteorol. Res., vol. 28 (5), 2014, pp. 983-1002.

[9] Williams, E.R. Large-scale charge separation in thunderclouds. J. Geoph. Res., vol. 90(D4), 1985, 6013.

[10] Barthe C., Deierling W., Barth M.C. Estimation of total lightning from various storm parameters: A cloud-resolving model study. J. Geophys. Res. Atmos., vol. 115, 2010, pp. 1-17.

[11] Wapler K., James P. Thunderstorm occurrence and characteristics in Central Europe under different synoptic conditions. Atmos. Res., vol. 158-159, 2015, pp. 231-244.

[12] Meyer V.K., Höller H., Betz H.D. The temporal evolution of three-dimensional lightning parameters and their suitability for thunderstorm tracking and nowcasting. Atmos. Chem. Phys., vol. 13, 2013, pp. 5151-5161.

[13] Smith S.B., LaDue J.G., MacGorman D.R. The relationship between cloud-to-ground lightning polarity and surface equivalent potential temperature during three tornadic outbreaks. Mon. Weather Rev., vol. 128, 2000, pp. 3320-3328.

[14] Carey L.D., Buffalo K.M. Environmental control of cloud-to-ground lightning polarity in severe storms. Mon. Weather Rev., vol. 135, 2007, pp. 1327-1353.

[15] Changnon S.A. Note on hailstone size distributions. J. Appl. Meteo., vol. 10, 1971, pp. 168-180.

[16] Changnon S.A. Hailfall characteristics related to crop damage. J. Appl. Meteo., vol. 10, 1971, pp. 270-274 
[17]Csirmaz K., Simon A., Pistotnik G., Polyánszky Z., Neštiak M., Nagykovácsi Z., Sokol A. A study of rotation in thunderstorms in a weakly- ormoderately-sheared environment. Atmos. Res., vol. 123, 2013, pp. 93-116.

[18] Deierling W., Petersen, W.A. Total lightning activity as an indicator of updraft characteristics. J. Geophys. Res. Atmos., vol. 113, 2008, 16.

[19] Dotzek N., Friedrich K. Downburst-producing thunderstorms in southern Germany: radar analysis and predictability. Atmos. Res., vol. 93, 2009, pp. 457-473.

[20] Makitov V. Radar measurements of integral parameters of hailstorms used on hail suppression projects. Atmos. Res., vol. 83, 2007, pp. 380-388.

[21] López L., Sánchez J.L. Discriminant methods for radar detection of hail. Atm. Res., vol. 93, 2009, 358.

[22] Schleusener R.A., Jennings P.C. An energy method for relative estimates of hail intensity. Bull. Am. Meteorol. Soc., vol. 41, 1960, pp. 372-376.

[23] Sioutas M., Meaden T., Webb J.D.C. Hail frequency, distribution and intensity in Northern Greece. Atmos. Res., vol. 93, 2009, pp. 526-533.

[24] Sánchez J.L., López L., Garca-Ortega E., Gil, B. Nowcasting of kinetic energy of hail precipitation using radar. Atmos. Res., vol. 123, 2013, pp. 48-60.

[25] Pascuzzi S., Santoro F. Evaluation of farmers' OSH hazard in operation nearby mobile telephone radio base stations. Proceedings of 16th International Scientific Conference "Engineering for Rural Development", May 24-26, 2017, Jelgava, Latvia, vol. 16, pp. 748-755. Available at: https://doi.org/10.22616/ERDev2017.16.N151

[26] Chiu S., Cheyney M., Ramirez M., Gerr F. Where do agricultural producers get safety and healthinformation? Journal Of Agromedicine, vol. 20(3), 2015, pp. 265-272.

[27] Cerruto E., Manetto G., Santoro F., Pascuzzi S. Operator Dermal Exposure to Pesticides in Tomato and Strawberry Greenhouses from Hand-Held Sprayers. Sustainability, vol. 10(7), 2018, 2273. Available at: https://doi.org/10.3390/su10072273

[28] Armstrong H., Whitehead E. Field and Analytical Studies of Transmission Line Shielding. IEEE Trans. Power Appar. Syst., vol. PAS-87, 1968, pp. 270-281.

[29] Berger K., Anderson R.B., Kroninger H. Parameters of lightning flashes. Electra, vol. 41, 1975, pp. 23-37.

[30] Borghetti A., Napolitano F., Nucci C.A., Tossani F. Influence of the return stroke current waveform on the lightning performance of distribution lines. IEEE Trans. Power Deliv., vol. 32, 2017, pp. 1800-1808.

[31] Borghetti A., Napolitano F., Nucci C.A., Tossani F. Response of distribution networks to direct and indirect lightning: Influence of surge arresters location, flashover occurrence and environmental shielding. Electr. Power Syst. Res., vol. 153, 2017, pp. 73-81.

[32] Dellera L., Garbagnati E. Lightning stroke simulation by means of the leader progression modelPart I. IEEE Trans. Power Deliv., vol. 5, 1990, pp. 2009-2022.

[33] Dellera L., Garbagnati E. Lightning stroke simulation by means of the leader progression modelPart II. IEEE Trans. Power Deliv., vol. 5, 1990, pp. 2023-2029.

[34] Berger K., Garbagnati E. Lightning current parameters. Results obtained in Switzerland and in Italy. In Proceedings of the Conference "URSI", 28 August-5 September, 1984, Florence, Italy, pp. 1-11.

[35] Borghetti A., Nucci C.A., Paolone, M. Estimation of the statistical distributions of lightning current parameters at ground level from the data recorded by instrumented towers. IEEE Trans. Power Deliv., vol. 19, 2004, pp. 1400-1409.

[36] Santoro F., Anifants A.S., Ruggiero G., Zavadskiy V., Pascuzzi S. Lightning Protection Systems Suitable for Stables: A Case Study. Agriculture, vol. 9(4), 2019, 72. Available at: https://doi.org/10.3390/agriculture9040072

[37] Borghetti A., Nucci C.A., Paolone M. Indirect-Lightning Performance of Overhead Distribution Networks With Complex Topology. IEEE Trans. Power Deliv., vol. 24, 2009, pp. 2206-2213.

[38] Anderson R.B., Eriksson A.J. Lightning param for engineering. Electra, vol. 69, 1980, 65-102.

[39] Nucci C.A. Lightning-induced voltages on distribution systems: Influence of ground resistivity and system topology, J. Lightn. Res., vol.1, 2007, pp. 148-157. 
[40]Borghetti A., Morched A.S., Napolitano F., Nucci C.A., Paolone M. Lightning-induced overvoltages transferred through distribution power transformers. IEEE Trans. Power Del., vol. 24(1), 2009, pp. 360-372.

[41] Napolitano F. An analytical formulation of the electromagnetic field generated by lightning return strokes. IEEE Trans. Electromagn. Compat., vol. 53(1), 2011, pp. 108-113

[42] Uman M.A., Mclain, D.K. Magnetic field of lightning return stroke. J. Geophys.Res., vol. 74, 1969, pp. 6899-6910.

[43] Uman M. The Art and Science of Lightning Protection. Cambridge University Press, 2008

[44] Nakada K., Sugimoto H., Yokoyama S. Experimental facility for investigation of lightning performance of distribution lines. IEEE Trans. Power Deliv., vol. 18, 2003, pp. 253-257.

[45] Miyazaki T., Okabe S. A detailed field study of lightning stroke effects on distribution lines, IEEE Trans. Power Deliv., vol. 24, 2009, pp. 352-359.

[46] IEEE Std C62.82-2010 "IEEE Standard for insulation coordination-definitions, principles, and rules."

[47] IEEE StdC57, 142-2010 "IEEE Guide to describe the occurrence and mitigation of switching transients induced by transformers, switching device, and system interaction."

[48] Anifantis A.S., Pascuzzi S., Scarascia Mugnozza G. Geothermal source heat pump performance for a greenhouse heating system: An experimental study. Journal of Agricultural Engineering, vol. 47(3), 2016, pp.164-170.

[49] Anifantis A.S., Camposeo S., Vivaldi G.A., Santoro F., Pascuzzi S. Comparison of UAV photogrammetry and 3D modeling techniques with other currently used methods for estimation of the tree row volume of a super-high-density olive orchard. Agriculture (Switzerland), vol. 9(11), 2019, 233. Available at: https://doi.org/10.3390/agriculture9110233

[50] Pascuzzi S., Cerruto E. An innovative pneumatic electrostatic sprayer useful for tendone vineyards. Journal of Agricutural Engineering, vol. 46(3):458, 2015, pp. 123-127.

[51] Bulgakov V., Pascuzzi S., Nadykto V., Ivanovs S. A mathematical model of the plane-parallel movement of an asymmetric machine-and-tractor aggregate. Agriculture, vol.8(10), 2018, 151.

[52] Bulgakov V., Pascuzzi S., Santoro F., Anifantis A.S. Mathematical Model of the Plane-Parallel Movement of the Self-Propelled Root-Harvesting Machine. Sustainability, vol. 10(10), 2018, 378. Available at: https://doi.org/10.3390/su10103614

[53] Sobczak P., Zawiślak K., Panasiewicz M., Mazur J., Kocira S., Żukiewicz-Sobczak W. Impact of heat treatment on the hardness and content of anti-nutritious substances in soybean seeds. Carpathian Journal of Food Science and Technology, vol 10(5), 2018, pp. 46-52.

[54] Panasiewicz M., Mazur J., Sobczak P., Zawiślak K., Kraśnicka K., Kupryaniuk K. The chemical composition of powdered pumpkin pulp and its application for food purposes. Przemysł Chemiczny, vol. 97(5), 2018, pp. 758-761, DOI: 10.15199/62.2018.5.21

[55] Przywara A., Kachel-Jakubowska M., Kraszkiewicz A., Koszel M. Comparision of physicochemical parameters of rape seeds applying the infrared spectroscopy method. Proceedings of IX International Scientific Symposium "Farm machinery and processes management in sustainable agriculture": November 22-24, 2017, Lublin, Poland, pp. 324-329.

[56] Przywara A., Kachel M., Koszel M., Leszczyński N., Kraszkiewicz A., Anifantis A.S. The influence of digestate on the static strength of spring rapeseeds (Brassica napus var. arvensis). Sustainability, vol. 11(7), 2019, 2133.

[57] Kraszkieicz A., Kachel M., Parfiniuk S., Zając G., Niedziółka I., Sprawka M. Assessment of the possibility of using hemp biomass (Cannabis sativa L.) for energy purposes: a case study. Appl. Sci., vol. 9(20), 2019, 4437.

[58]EN 62305-1 "Protection against Lightning-Part 1 General Principles."

[59]EN 62305-2 "Protection against Lightning-Part 2 Risk Management."

[60]EN 62305-3 "Protection against Lightning-Part 3 Physical Damage to Structure and Life Hazard."

[61]EN 62305-4 "Protection against Lightning-Part 4 Electrical and Electronic Systems within Structures. 